ІНТЕГРАЛЬНА ДІАГНОСТИКА ЕМОЦІЙНИХ ПОРУШЕНЬ У ДІТЕЙ

\title{
THE INTEGRAL DIAGNOSTICS OF EMOTIONAL DISORDERS IN CHILDREN
}

УДК 616.89-008.44-053.2-079.4 DOI https://doi.org/10.32843/26635208.2020.12-2.23

\section{Кабанцева А.В.}

к.психол.н., доцент кафедри психіатрії, психотерапії, наркології

і медичної психології

Донецький національний

медичний університет

Панченко О.А.

д.мед.н., профресор,

заслужений лікар України, президент

Всеукраїнська професійна

психіатрична ліга

Цапро Н.П.

лікар-педіатр, дитячий

кардіоревматолог вищої категорії

Державний заклад

«Науково-практичний медичний

реабілітаційний центр

Міністерства охорони здоров'я України» у статті наводиться аналіз методів дослідження емоційних порушень у дітей, зазначено фрактори, що впливають на їхній розвиток, а також розглядаються ключові складники діагностики зазначених відхилень. Автори вказують, що емоції є індикатором психологічного комфорту, регулюють поведінку, беруть участь у процесах соціалізаціі й адаптації, корелюють внутрішній стан із зовнішніми проявами соціально-психічного благополуччя, впливають на якість життя дитини. Ураховуючи багатогранності життєвої ссрери, акцент робимо на комплексномудослідженні емоційнихпорушень івстановленні їх наслідків, пропонуємо проведення інтегральної діагностики з використанням інфрормаційного кейсу реєстрації анамнезу особливостей розвитку дитини. Для реалізації останнього представлена авторська розробка «Карта клініко-психологічного та соціального обстеження дитини». Наводяться результати власних досліджень емоційних порушень у дітей Донецького регіону, ї взаємозалежності з фрізичним і психічним здоров'ям, внутрішньосімейним кліматом як первісною соціальною зоною розвитку. Установлено взаємозв'язок між показниками тривожності й порушенням серцевого ритму. Ця особливість свідчить про негативний вплив відчуття занепокоєння на роботу серцево-судинної системи $(r=0,912, p<0,05)$. Також зазначено прямий кореляційний зв'язок між тривожними проявами з астенічними рисами та фрункціональними розладами шлунково-кишкового тракту $(r=822, \quad p<0,05)$. Несприятлива сімейна атмоссрера (напружені взаємини між подружжям, шкідливі звички батьків, неповні сімі) форомує в дітей почуття самотності й незахищеності ( $r=0,69, p=0,01)$. Результати проведених досліджень обгрунтовують дієвість інтеграційної діагностики, $\epsilon$ есрективним інструментом в організації заходів медико-психолого-педагогічної реабілітації.

Ключові слова: Донецький регіон, дирреренційний підхід, корекція, комплексне обсте- ження, психодіагностика, психологічний стан, соматичні прояви, реабілітація.

In the article, scientists provide an analysis of methods for studying emotional disorders in children, noted factors that influence their development, and also discusses the key components of the diagnosis of these deviations. The authors note that emotions act as an indicator of psychological comfort, regulating behavior, take part in the processes of socialization and adaptation, correlate the internal state with external manifestations of social and psychological well-being, affecting the quality of life of the child. Given the versatility of the life sphere, the emphasis is on a comprehensive study of emotional disorders and the establishment of their consequences, it is proposed to conduct integral diagnostics using an information case for registering an anamnesis of the features of a child's development. To implement the latter, the author's development "Map of the clinical, psychological and social examination of the child is presented". The results of our own studies of emotional disorders in children of the Donetsk region, their interdependence with physical and mental health, the internal-family climate, as the primary social development zone, are presented. The relationship between the indicators of anxiety and heart rhythm disturbance is established. This feature indicates a negative effect of anxiety on the functioning of the cardiovascular system ( $r=0.912$, $p<0.05)$. A direct correlation between anxiety manifestations with asthenic features and functional disorders of the gastrointestinal tract is also indicated $(r=822, p<0.05)$. An unfavorable family atmosphere (tensions between spouses, bad habits of parents, single-parent families) forms a feeling of loneliness and insecurity in children $(r=0.69, p=0.01)$. The results of the studies justify the effectiveness of integration diagnostics, and is an effective tool in organizing medical-psychological-pedagogical rehabilitation events. Key words: Donetsk region, differential approach, correction, comprehensive examination, psychodiagnosis, psychological state, somatic manifestations, rehabilitation.
Постановка проблеми. Значення емоційної сфери щодо повноцінного розвитку особистості дитини має давню історію й залишається актуальною проблемою сучасних досліджень [1-5]. Емоції дитини відображають актуальний психоемоційний стан, який, у свою чергу, впливає на різні види діяльності та якість життя загалом. Вони реалізуються в психічному розвитку, а саме регулюють поведінку, беруть участь в оволодінні дитиною засобами та способами взаємодії з однолітками й дорослими, процесах соціалізації й адаптації. Також $€$ ланцюжком між внутрішнім станом і зовнішніми проявами соціально-психічного благополуччя, індикатором психологічного комфорту.
Сьогодні все частіше діти стають жертвами домашнього насильства, опиняються в зонах стихійних і природних катастроф, військових дій, зазнають впливу інформаційних атак і фейків тощо. Психотравмуючі події навантажують психічні, фізіологічні та адаптаційні можливості дорослої людини, а в дитячому віці ці механізми ще недостатньо сформовані, тому подібні стани є справжнім випробуванням на міцність дитячого організму. Наслідками цих дій є зміни в організмі дитини, що відбуваються на всіх його рівнях: психологічному, психічному та соматичному. Емоційні проблеми в дітей можуть мати серйозні наслідки для психічного здоров'я й розвитку та реалі- 
зації особистості загалом. Важливо розуміти причини, симптоми, прогноз і те, які методики корективного втручання $є$ найкращими, щоб виявляти емоційні порушення та запобігати їм. Тому інтегральна діагностика емоційних порушень - актуальний напрям діагностики психічного, фізичного здоров'я та психологічного благополуччя дитини в часи соціально-психологічної нестабільності суспільства.

Аналіз останніх досліджень і публікацій. Проблемі діагностики емоційних порушень присвячено велику кількість наукових робіт з використанням різноманітних методів і методик (Г. Бреслав, О. Запорожець, Д. Ельконін, О. Ізотова, В. Іванкова, О. Леонтьєва, Л. Нікіфорова, Г. Хоментаускас, П. Якобсон та інші). 3 огляду на вікові особливості, реалізація проективних методів є головним діагностичним засобом у роботі з дітьми дошкільного віку (З. Огороднійчук, Л. Руденко, Н. Малафій). Також інформативними психологічними методами є бесіда з батьками, анкетування й спостереження. I для більш точної діагностики необхідним $€$ системне застосування цих методів.

Необхідність своєчасного обстеження пов'язана з винятковим значенням ранніх етапів онтогенезу в становленні особистості. За рахунок швидкого темпу розвиток непоміченої функціональної патології в дитячому віці призводить у дорослому періоді до порушень, що впливають на гармонійний розвиток особистості, професійну сферу та якість життя загалом [6, с. 41].

Утім саме в дитинстві є доволі широкі можливості для своєчасного відновлення й корекції негараздів психічної та соматичної сфер. Різнобічне й ефективне обстеження можна досягти завдяки достатній пластичності, чутливості, компетентності й високій кваліфікації фахівців, які досліджують дитину, відновлюють ї̈̈ здоров'я [7, с. 154-127; 8, с. 536-541; 9, с. 3].

Теоретико-методологічний аналіз проведених раніше досліджень показав однобічність, фрагментарне вивчення емоційних порушень, їх корекція має психолого-педагогічний характер. Варто відмітити, що важливою $є$ не діагностика заради діагностики як такої, а задля надання повноцінної ґрунтовної допомоги дитини, яку вона потребує в цей час. I найчастіше ця допомога не окреслюється лише психолого-педагогічними заходами, а й потребує медико-психологічного спрямування, бо виявлення порушень відбувається в дедалі пізньому періоді, коли психологічні проблеми мають уже психосоматичні прояви.

Отже, об'єктивізація стану здоров'я дитини охоплює багатогранність складників спектрів якості її життя: фізичний, психічний, психофізіологічний розвиток, психологічна рівновага, а також педагогічний вплив і соціальне ото- чення. Своєчасність оцінювання відповідності норм розвитку психологічного та функціонального стану дитини важливе передусім з метою:

- раннього виявлення можливих відхилень;

- планування своєчасних психологічних, педагогічних, медичних заходів профілактики й корекції окремих сторін фізичного та психологічного розвитку.

Соціальне оточення, у якому народжується дитина та специфіку якого поступово засвоює, впливає на особистісний розвиток. Зокрема, емоційний розвиток відбувається поступово, завдяки взаємодії дитини з людьми, які її оточують. Постійне розширення емоційного досвіду, його змісту й почуттєвої забарвленості координують спрямованість діяльності, тому в дітей дошкільного віку досить ретельно оцінюються показники настрою та поведінки, зокрема їхнє безпосереднє емоційне реагування [10, с. 145-146].

Рідні, взаємини з ними, особливості спілкування та духовні цінності визначають соціальне середовище дитини й умови її становлення. Наприклад, внутрішньосімейні взаємини закладають провідну стратегію емоційного реагування та загальної поведінки дитини в майбутньому. Отже, установлення якості сімейного клімату $€$ доречним в об'єктивізації стану дитини [11, с. 192-203]. Також значної інформативності набувають дані щодо встановлення методів заохочення та покарання в колі сім'ї.

Доцільно приділити увагу вивченню взаємодії дитини з оточенням (із дітьми та близькими дорослими), у ньому вона виділяє найбільш значимі для себе соціальні цінності. Визначені соціальні орієнтири дають змогу опанувати встановлені правила, зразки, еталони поведінки, що регулюють соціальне життя, зокрема визначають межі дозволеного щодо конкретних умов діяльності [12; 13].

Як уже зазначено, не розв'язані своєчасно психологічні проблеми несуть загрозу для соматичного здоров'я, тому необхідною є діагностика функціонального стану органів і систем. Останнє визначається за частотою серцевих скорочень і дихання, рівнем артеріального тиску, лабораторними даними. Повний аналіз клінічного, лабораторного та інструментального дослідження дає змогу об'єктивно оцінити стан здоров'я дитини. Важливим складником стану соматичного здоров'я дитини визначається ступінь резистентності організму до несприятливих впливів, що проявляється в схильності до захворювань [12, с. 34].

З огляду на багатогранності життєвої сфери дитини, виникає необхідність у розробленні діагностичного інструментарію, який би включав всі вищезазначені структурні елементи.

Постановка завдання. Мета статті - розробити інтегральний діагностичний інстру- 
ментарій для комплексного дослідження дітей з проявами емоційних порушень, які мешкають у соціально-напружених умовах.

Дослідження проводилося на базі державного закладу «Науково-практичний медичний реабілітаційно-діагностичний центр Міністерства охорони здоров'я України». У ньому взяли участь діти 5-7 років з проблемами в нервово-психічній і соматичній сферах. Кількість дітей - 1308 осіб дошкільного віку. Середній вік

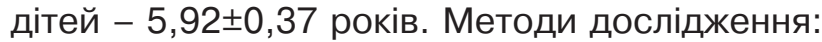
психологічні, медичні, статистичні. Психологічними методами були анкетування, бесіда, тестування. Анкетування проводилося за авторською розробкою «Карта клініко-психологічного та соціального обстеження дитини». Ураховуючи вікові особливості респондентів, тестування проводили проективними методиками: «Паровозик» (С. Вєлієва), «Неіснуюча тварина» (М. Друкаревич), «Кактус» М. Панфілової, опитувальник страхів А. Захарова, тест «Драбина» (В. Щур), «Малюнок сім'ї» Г. Хоментаускас. Медичні методи: первинний огляд лікаря, функціональні методи (визначення варіабельності серцевого ритму за даними електрокардіограми (ЕКГ), холтерівське моніторування, спірометрія, ехокардіоскопія (ЕХО-КС), реовазограма (РЕГ), електроенцефалоскопія (ЕХO-EC). Статистична обробка даних проводилася за допомогою програми IBM SPSS Statistics 20.

Виклад основного матеріалу дослідження. У рамках науково-дослідницької роботи «Розробка системи медико-психологічної допомоги дітям та підліткам, що перебувають у зоні проведення антитерористичної операції» (номер державної реєстрації 0116U004162) за результатами проведених досліджень [7; 14; 15,] розроблено єдиний інформаційний кейс реєстрації анамнезу особливостей розвитку дитини у вигляді «Карта клініко-психологічного та соціального обстеження дитини».

Визначаючи основні компоненти бесіди з батьками та безпосередній огляд дитини, робимо акцент на таких структурних елементах:

- біологічний анамнез (перинатальний онтогенез). Надає дані про анте-, інтрата постнатальний періоди життя дитини та фактори, що несприятливо впливають на їх перебіг;

- психологічний анамнез. Охоплює емоційні, особистісні та поведінкові риси дитини;

- соціальний анамнез (склад сім'ї, освіта батьків, бюджет і побутові умови, психологічні установки сім'ї);

- педагогічний анамнез. Ураховує особливості соціальної адаптації в колективі, поглиблений характер оцінки під час установлення міжособистісних стосунків, уподобання різноманітних видів ігор і статусні позиції у взаєми- нах. Дані педагогічного анамнезу дають змогу корегувати та передбачати прояви дезадаптації внаслідок відхилень у розвитку.

Представлена Карта дає змогу комплексно оцінити стан здоров'я й розвитку дитини 5-7 років за чотирма блоками: соціальним, медичним, педагогічним і психологічним. Карта розроблена у вигляді анкети, з якою ознайомлюють батьків, отримують від них згоду на їі заповнення. Опитування за Картою проводиться на первинному прийому у фахівця (психолог, педіатр), який самостійно збирає анамнез розвитку дитини та враховує їі соціальні характеристики. Заповнення психологічного й педагогічного блоків здійснюється батьками самостійно. У кінці Карти батьками ставиться відмітка про правдивість наданої інформації, що затверджується особистим підписом.

Перший «Соціальний» блок Карти вміщує в себе загальну інформацію про дитину та її батьків, а саме: персональні дані (прізвища, ім'я по батькові, рік народження, адреса проживання), соціальна категорія дитини, соціально-побудові умови, склад сім'ї, загальна кількість дітей, яка дитина за рахунком народжування; освіта батьків, їхні звички, захоплення, відмічаються як позитивні, як і шкідливі. Також до цього блоку входять додаткові запитання про інших членів родини або дорослих, що беруть активну участь у зростанні та вихованні дитини, визначається авторитетний дорослий для дитини. Запитання цього блоку спрямовані, по-перше, на первинне ознайомлення з дитиною та її сім'єю; по-друге, допомогу фахівцю уявити, з якою дитиною та сім'єю потрібно буде працювати, які форми взаємодії та спілкування треба використовувати, щоб робота була ефективною.

Для вирішення актуальних проблем дитини на час звернення до фахівця необхідним $є$ вивчення розвитку дитини від самого моменту запліднення до моменту звернення. Саме цьому присвячений другий блок Карти («Медичний» блок), що вміщує інформацію про протікання, особливості або складності, що виникали під час вагітності або пологів. Акцент робиться на вивченні стану здоров'я матері, порядку народження дитини, її антропометричних даних, виду годування (грудне чи штучне, так як тип годування впливає на формування імунної системи, формує відчуття психологічної безпеки). За наявності обов'язково враховуються вроджені патології, а також бажання батьків щодо появи дитини в сім'ї, психологічний стан жінки під час вагітності й пологів, так як діти надзвичайно чутливі до станів матері, її емоційного настрою. Наслідки останнього впливають на розвиток малюка в майбутньому. У цьому блоці також досліджуються ранній розвиток дитини, перенесені 
хвороби, їх наслідки, наявність консультацій і диспансерний облік у лікарів.

Третій «Педагогічний» блок включає інформацію про психічний розвиток і виховання дитини. Запитання укомплектовані так, що дають змогу вивчити дошкільну освіченість дитини: відвідування закладу дошкільної освіти, проходження адаптаційного періоду, мовленнєвий розвиток, переважні захоплення, дотримання правил гри й порядку, товариськість, характер взаємодії з іншими дітьми та дорослими. Також досліджується участь батьків у вихованні й розвитку дитини: кількість приділеного часу, як саме проводиться час з дитиною, які використовуються форми й методи спільної праці та відпочинку, заходи заохочення й міри покарання.

Останній «Психологічний» блок присвячений індивідуально-психологічним особливостям дитини. На цьому етапі досліджуються переважний емоційний фон, позитивні та негативні якості характеру, звички, погані прояви поведінки. Оцінюється цілеспрямованість, дружелюбність, конфліктність, сором'язливість, самооцінка, а також поведінка дитини у звичайних соціальних та емоційно значущих ситуаціях. Особливості поведінки враховують характер настрою (бадьорий, спокійний, дратівливий, пригнічений, нестійкий); засинання (повільне, спокійне, швидке, неспокійне); сну (глибокий, спокійний, неспокійний, за тривалістю - нормальний, короткий, довгий); апетиту (хороший, нестійкий, поганий, вибіркове ставлення до їжі). Досліджуються індивідуальні особливості (контактність, сором'язливість, уразливість, рівень працездатності, агресивність, ініціативність тощо). Вивчаються дитячо-батьківські взаємини, система міжособистісних установок, цінностей та орієнтацій, очікування батьків від дитини. Прискіплива оцінка поведінки, емоційних реакцій дітей 5-7 років зумовлена необхідністю прогнозування якості соціальної взаємодії в майбутньому, розладів особистості та своєчасного встановлення ознак дезадаптаційних проявів.

За розробленою Картою проведено анкетування, що дало змогу об'єктивізувати стан дітей з боку тієї інформації, яку надали батьки, визначити вектори подальшої медико-психологічної діагностики й установити певні взаємозв'язки між причинами порушень і їх наслідками, а також спланувати подальший реабілітаційний маршрут.

У загальній когорті дослідження встановлено страхи різного характеру $(61,2 \%)$, наявність тривожності, занепокоєності, хвилювання (53,2\%), прояви агресивності (36,7\%), низької самооцінки (18,4\%). Понад половина респондентів мали страх фізичного збитку і страх війни. Також високі відсотки діагностовано серед соціальних, медичних, просто- рових, тваринних страхів і страху темряви (таблиця 1).

у 57,4\% дітей, що взяли участь у дослідженні, установлено відчуття одинокості, незахищеності в сім'ях. Поряд із цим під час дослідження дитячо-батьківських взаємин установлено, що сприятливу сімейну атмосферу мають 966 осіб (72,6\%), несприятливу внутрішньосімейну ситуацію - 342 особи $(27,3 \%)$.

Таблиця 1

Наявні страхи дітей сходу України

\begin{tabular}{|c|c|c|}
\hline Види страхів & $\begin{array}{c}\text { Кількість рес- } \\
\text { пондентів }\end{array}$ & \% \\
\hline Страх фізичного збитку & 704 & 53,8 \\
\hline Страх війни & 644 & 51,5 \\
\hline Медичні страхи & 575 & 45,1 \\
\hline Соціальні страхи & 564 & 45,1 \\
\hline Страхи темряви & 577 & 46,2 \\
\hline Страх тварин & 442 & 35,4 \\
\hline Відкриті простори & 361 & 31,3 \\
\hline
\end{tabular}

Після лікарського огляду, проведення функціональних досліджень виявлено патологічні зміни в дітей з боку фізичного здоров'я. Порушення в кістково-м'язовій системі встановлено у 253 дітей (19,3\%), розлади шлунково-кишкового тракту - 295 дітей $(22,5 \%)$, порушення серцево-судинної системи у 554 дітей (42,3\%),

Під час комплексного дослідження стану здоров'я дитини з використанням Карти клініко-психологічного та соціального обстеження, психодіагностичних і функціональних методів установлено взаємозв'язок між показниками тривожності й порушенням серцевого ритму. Ця особливість свідчить про негативний вплив відчуття занепокоєння на роботу серцево-судинної системи $(r=0,912, p<0,05)$. Також установлено прямий кореляційний зв'язок між тривожними проявами з астенічними рисами та функціональними розладами шлунково-кишкового тракту $(r=0,822, p<0,05)$. Порушення в кістково-м'язовій системі, що пов'язані з малорухливим способом життя, виявлено серед дітей, які довгий час проводять з інформаційними носіями: комп'ютером, планшетом або телефоном ( $r=0,763, p<0,05)$.

Аналіз пренатального анамнезу та психоемоційного стану дітей дав змогу встановити тісний взаємозв'язок між наявністю асфіксії та схильністю до нав'язливих рухів у дітей дошкільного віку $(r=0,717, p \leq 0,01)$

Вивчення дитячо-батьківських взаємин допомогло встановити взаємозв'язки між типом взаємовідношень і психологічними особливостями дітей. Так, діти з тривожними рисами більш зустрічалися в сім'ях з ієрархічними взаєминами - 456 дітей (34,8\%); харак- 
тер афективних проявів у дітей, тобто наростаюче емоційне напруження зареєстровано в сім'ях з надмірно вимогливими батьками 248 сімей $(18,9 \%)$.

Статистично встановлено, що несприятлива сімейна атмосфера (складні взаємини між подружжям, шкідливі звички батьків, неповні сім'ї) формує в дітей почуття самотності й незахищеності $(r=0,69, p=0,01)$, а це, у свою чергу, негативно впливає на самооцінку та соціалізацію дітей.

3 огляду на тісну взаємодію психічної та соматичної сфер, виникає обґрунтована необхідність сумісних заходів у реабілітаційному процесі щодо відновлення психологічної рівноваги, соматичного стану, нормалізації процесів збудження та гальмування нервової системи, оволодіння релаксаційними техніками, розв'язання внутрішньоособистісних і міжособистісних конфліктів, конструктивного вираження негативних емоцій тощо. Зокрема, психологічна корекція планується в рамках індивідуальної, групової роботи та сімейної психотерапії.

Розроблена методологічна структура Карти й систематизованість отриманих даних дають змогу встановити взаємозв'язки між особливостями розвитку, соціальним середовищем і характерними особливостями дитини. Також дається можливість установити глибинні причини актуальних проблем соматичного, психологічного, психічного характеру, окреслити фактори наявного ризику розвитку психосоматичних порушень, психологічної дисгармонії особистості дитини.

Висновки з проведеного дослідження. Отже, на основі викладеного вище, можемо резюмувати таке:

1. Розроблена Карта клініко-психологічного та соціального обстеження дитини дала змогу встановити наявність емоційних порушень, провести їх диференціацію, визначити реалізацію стресу в психосоматичній сфері, оцінити й виявити симтомокомплекси, що потребують психокорекційних заходів, медичного втручання, лікування та реабілітації.

2. Емоційні порушення в дітей унаслідок стресового навантаження в соматичній сфері розподілилися так: порушення серцево-судинної системи - 42,3\%, розлади шлунково-кишкового тракту - 22,5\%, порушення в кістково-м'язовій системі - 19,3\%.

3. Несприятлива сімейна атмосфера (байдужі взаємини між членами сім'ї, напружені взаємини між подружжям, шкідливі звички батьків, неповні сім'ї тощо), що притаманна 27,3\% респондентів, формує почуття самотності й незахищеності в дітей $(r=0,69, p=0,01)$, як наслідок, може набувати соматичного характеру.

4. У 554 дітей $(42,35 \%)$ виявлено порушення серцево-судинної системи. Установ- лено прямий взаємозв'язок між показниками тривожності та порушенням серцевого ритму $(r=0,912, p<0,05)$. Ця особливість свідчить про негативний вплив відчуття занепокоєння на роботу серцево-судинної системи. Також зазначено прямий кореляційний зв'язок між тривожними проявами з астенічними рисами й функціональними розладами шлунково-кишкового тракту $(r=822, p<0,05)$.

5. Проведене дослідження обумовлює співпрацю лікарів, психологів, педагогів і батьків під час установлення розладів у дитині. Результати проведених досліджень обґрунтовують дієвість інтеграційної діагностики, $€$ ефективним інструментом в організації заходів медико-психолого-педагогічної реабілітації.

\section{ЛITEPATУРA:}

1. Halle T.G., Darling-Churchill K.E. Review of measures of social and emotional development. Journal of Applied Developmental Psychology. 2016. Vol. 45. P. 8-18.

2. Parhomenko K. Diagnostic Methods of SocioEmotional Competence in Children. Procedia-Social and Behavioral Sciences. 2016. Vol. 146. P. 329-333.

3. Одинцова В.В., Горчакова Н.М. Эмоциональное благополучие как интегративная характеристика эмоциональной сфреры. Вестник СПбГУ. Серия 12. 2014. Вып. 1. С. 69-77.

4. Фаустова И.В., Гамова С.Н. Эмоциональное благополучие ребенка-дошкольника как предпосылка развития его эмоциональной устойчивости. Современные проблемы науки и образования. 2016. № 6. URL: http://www.science-education.ru/ru/article/ view?id=25510 (дата обращения: 15.04.2020).

5. Кабанцева А.В. Соціалізація дітей з емоційними порушеннями. Актуальні проблеми психолоzії : збірник наукових праць Інституту психології імені Г.С. Костюка НАПН України. 2019. Вип. 52. Т. 1 : Організаційна психологія. Економічна психологія. Соціальна психологія. С. 76-82.

6. Цыбульская Е.А. Использование символических средств при решении познавательных задач старшими дошкольниками. Психологическая наука и образование. 2015. Т. 7. № 1. С. 39-47.

7. Kabantseva A. Medical psychological approaches to rehabilitation process for children who suffer of various emotional disorders / XXIV edycja Międzynarodowego Dnia Inwalidy (15-17 marca 2018). Zgorzelec : Konferencja Naukowa Polska, 2018. № 3 (6). P. 145-147.

8. Melissa J., Hagan M. J., Gentry M., Ippen C.G., Alicia F. PTSD with and without dissociation in young children exposed to interpersonal trauma. Journal of Affective Disorders. 2018. Vol. 227. P. 536-541.

9. Цуциева Ж.Ч. Принципы и особенности реабилитации детей и подростков - жертв террористического акта : автореср. дисс. ... докт. психол. наук : 19.00.04. Санкт-Петербург, 2010. 56 с.

10. Panchenko O.A., Symonenko E.B., Kabantseva A.V., Kayotkina N.A., Minakova E.N. Children's health psychologic aspect in ATO. International Conference 


\section{ГАБІТУС}

on ICT Management for Global Competitiveness and Economic Growth in Emerging Economies ICTM (22-23 october 2015). Wroclaw, Poland, 2015. P. 145-146.

11. Панченко О.А., Кабанцева А.В., Симоненко О.Б. Нові організаційні підходи до медико-психологічної допомоги дітям в умовах антитерористичної операції. Вісник Харківського національного педагогічного університету ім. Г.С. Сковороди. Серія «Психологія». Харків, 2017. № 55. С. 192-203.
12. Піроженко Т.О. Сучасні діти - відображення цінностей дорослого світу. Кіровоград, 2014. 81 с.

13. Клопотова Е.Е. Особенности ценностных ориентаций современных дошкольников. Психологическая наука и образование. Москва, 2017. № 1. С. 96-105.

14. Кабанцева А.В. Колаборація психологів, лікарів, педагогів у роботі з дітьми, які мають емоційні порушення. Теорія та практика сучасної психології. Запоріжжя, 2019. Вип. 1. С. 134-138. 